\title{
IMPLEMENTASI METODE ROTE LEARNING DALAM PEMBELAJARAN ILMU TAJWID
}

\author{
Ramhadi \\ Institute Agama Islam Negeri (IAIN) Curup \\ ramhadinisu@gmail.com \\ Fakhrudin \\ Institute Agama Islam Negeri (IAIN) Curup \\ Syamsul Rizal \\ Institute Agama Islam Negeri (IAIN) Curup
}

\begin{abstract}
The present study aimed at finding out the portrayal of rote learning method implementation which was applied by the coaches of TPQ al-Barokah in Kampung Melayu Village, Rejang Lebong, Bengkulu. This study used a qualitative approach. The data were gathered by means of observation and interview techniques. After the data were collected, the data were analyzed using phases referring to Miles, Huberman, and Saldana comprising data condensation, data display, and drawing conclusion. The findings of this study concluded that the rote learning method for Tajwid learning was considered very effective to be applied, and its merit was evident in students' competence in the recitation of Qur'an at TPQ al-Barokah. Their competence was seen when they were reexamined by their Qur'anic coaches, and they could provide examples of Tajwid's application in the Qur-an properly and correctly.
\end{abstract}

Keywords: implementation, rote learning method, learning, Tajwid

\begin{abstract}
Absrak
Penelitian ini bertujuan untuk memenukan gambaran tentang pelaksanaan metode role learning yang diterapkan oleh pembinak TPQ al-Barokah Desa Kampung Melayu Rejang Lebon, Bengkulu. Penelitian ini menggunakan pendekatan kualitatif. Data peroleh melalui teknik observasi dan wawancara dan setelah data terkumpul selanjutnya dianalisis dengan tahapan yang merujuk pada konsep Miles, Huberman dan Salda yakni, memilikan data, uraian data dan penarikan kesimpulan. Hasil penelitian ini memperoleh simpulan bahwa meteode rote Learning dalam ilmu tajwid dipandang sangat efektif untuk diterapkan dan terbukti terlihat manfaatnya pada bacaan al-Qur`an anak-anak asuh di TPQ
\end{abstract}


Al-Baroqah baik ketika dites kembali oleh guru ngaji yang bersangkutan dan dapat memberika contoh bacaan penerapan ilmu tajwid dalam Al-Qur`an dengan benar dan tepat.

Kata kunci: Implementasi, Metode Role Lerning, pembelajaran, Tajwid

\section{PENDAHULUAN}

Prosep pembelajaran dapat dikategorikan berhasil baik, jika kalau guru dalam proses tersebut berperan aktif dalam membangkitkan siswa agar proses belajar dapat berjalan secara baik dan efektif ${ }^{1}$. Bukan hanya mengenai metode atau prosedur yang digunakan dalam pengajaran, apakah pengajarannya itu klasik atau modern, apakah berdasarkan pengalaman di dunia pendidikan atau pada hasil percobaan. Dengan demikian syarat tentang pengajaran yang berhasil baik adalah sinergitas seluruh aspek pembelajaran, baik itu kompetensi guru, metode yang tepat, dan lain-lain.

Masa pendidikan konvensional, ada sebuah metode yang sering digunakan yaitu metode mengajar menghafal (Rote Learning $)^{2}$. Metode ini dinilai lebih teacher centered katimbang student-centered, lebih memberikan aktivitas mental, belajar dan faktor-faktor yang mempengaruhinya, ketimbang aktivitas fisik anak. Tidak ada salahnya jika guru mau mempelajarinya dan kemudian mencoba untuk menerapkannya. Sehingga pengertian metode rote learning atau hafalan adalah merupakan suatu

1 Alfian Erwinsyah, "Manajemen Kelas Dalam Meningkatkan Efektifitas Proses Belajar Mengajar," TADBIR: Jurnal Manajemen Pendidikan Islam 5, no. 2 (2017): 87-105; Wahyu Bagja Sulfemi, "Penerapan Model Pembelajaran Discovery Learning Meningkatkan Motivasi Dan Hasil Belajar Pendidikan Kewarganegaraan," Jurnal Rontal Keilmuan Pancasila Dan Kewarganegaraan 5, no. 1 (2019); Muldiyana Nugraha, "Manajemen Kelas Dalam Meningkatkan Proses Pembelajaran," Tarbawi: Jurnal Keilmuan Manajemen Pendidikan 4, no. 01 (2018): 27-44; Wahyu Astuti and Firosalia Kristin, "Penerapan Model Pembelajaran Teams Games Tournament Untuk Meningkatkan Keaktifan Dan Hasil Belajar IPA," Jurnal Ilmiah Sekolah Dasar 1, no. 3 (2017): 155-162.

2 Aisyah Nur Amalia, "Dinamika Tes Peringkat Hafalan," Al-Fanar: Jurnal Ilmu Al-Qur'an Dan Tafsir 2, no. 1 (2019): 1-14. 
teknik serta cara yang digunakan oleh seorang pendidik dengan menyerukan peserta didiknya untuk menghafalkan sejumlah kata-kata atau kalimat maupun kaidah-kaidah ${ }^{3}$.

Sedangkan dalam pendidikan kontemporer, istilah menghafal dan mengingat rote learning sudah sangat jarang digunakan, karena dalam pendidikan kontemporer kini lebih mementingkan proses penyelidikan, suatu pendekatan yang sering dikaitkan dengan taraf berfikir yang lebih tinggi sesuai dengan taksonomi Bloom ${ }^{4}$. Sementara metode mengingat dan menghafal dihubungkan dengan taraf berfikir yang rendah ${ }^{5}$. Sebagaimana fungsi dan tujuan pendidikan untuk pengembangan kemampuan individu dalam upaya mengatasi semua permasalahan baru yang muncul serta dapat mencari terobosan-terobosan solusi alternatif dalam menghadapinya ${ }^{6}$.

Salah satu upaya penting dalam hafalan menurut teori psikologi adalah daya mengingat atau memori ${ }^{7}$. Memori

${ }^{3}$ Eva Lutfiyah, "Pengaruh Penerapan Metode Rote Learning dalam Pembelajaran Al-Qur'an dan Hadits Terhadap Keberhasilan Membaca AlQur'aN (Studi Di MTs Negeri 2 Kota Serang" (PhD Thesis, Universitas Islam Negeri" Sultan Maulana Hasanuddin" Banten, 2018); Fitri Ardhiana Nur, "Perbandingan Efektivitas Metode Rote Learning Dan Metode Efektif Efisien Dalam Meningkatkan Kemampuan Membaca Al-Qur'an Sesuai Ilmu Tajwid Di SMP Negeri 3 Surabaya" (PhD Thesis, UIN Sunan Ampel Surabaya, 2018); Besse Tantri Eka, "Penerapan Metode Jibril Dalam Meningkatkan Kemampuan Menghafal Qs. al-Insyiqoq Ayat 1-25 di Ma'had al-Jami'ah UIN Raden Fatah Palembang (Skripsi)" (PhD Thesis, UIN Raden Fatah Palembang, 2016).

${ }^{4}$ I. Nyoman Temon Astawa, "Teori-Teori Dalam Dunia Pendidikan Modern," Jurnal Penjaminan Mutu 1, no. 1 (2016): 67-72.

5 Iin Sunarti and Nita Ristiani, "Pengaruh Penerapan Model Pembelajaran Problem Solving Berbasis Mind Mapping Terhadap Kemampuan Berpikir Kritis Siswa (Studi Eksperimen Pada Siswa Kelas VIII Mata Pelajaran IPS Terpadu Di SMP Negeri 1 Kuningan)," Equilibrium: Jurnal Penelitian Pendidikan Dan Ekonomi 15, no. 01 (2018): 18-34.

${ }^{6}$ Idi Warsah, "Interkoneksi Pemikiran Al-Ghazāli Dan Sigmund Freud Tentang Potensi Manusia," Kontekstualita 32, no. 01 (2018), http://ejournal.lp2m.uinjambi.ac.id/ojp/index.php/Kontekstualita/article/view/30.

${ }^{7}$ Fattah Hidayat, "Kajian Psikologi Pembelajaran Hafal Quran Bagi Anak Usia Dini," in Proceedings of The 2nd Annual Conference on Islamic Early Chilhood Education, vol. 3, 2017, 83-94; Aya Mamlu'ah, "Metode Lotre Pesantren Tahfidz Al-Qur'an At-Tauhid Leran Senori Tuban Analisis Terhadap Pencapaian Hafalan Al-Qur'an dan Permasalahannya," Visipena 
menjadi kerangka ingatan dalam struktur kehidupan manusia. Dalam memori ada dua kategori, yakni; eksplisit dan implisit. Memori eksplisit adalah ingatan yang diperoleh melalui usaha keras tertentu yang disengaja atau diniatkan. Sedangkan memori implisit adalah ingatan yang diperoleh secara organis dan otomatis melalui kerja sistem prsikis dalam tubuh manusia ${ }^{8}$. Hal itu dapat dilihat contohnya pada mendengarkan lagu yang diputar berkali-kali akan membuat anak dapat cepat mengingat kembali. Inilah contoh sederhana dari memori implisit dengan menjadikan informas itu terasa menyenangkan sehingga melekat erat di dalam orang sebagai pengetahuan yang tidak lepas dalam kurun waktu tertentu. Proses memasukkan infomasi dan konsep dilakukan secara natural.

Hafalan akan semakin kokoh apabila hal tersebut diamalkan. Inilah yang dilakukan oleh sahabat yang tidak akan berpindah hafalan sebelum mengamalkan apa yang dihafalkan ${ }^{9}$. Setiap ayat dapat dihubungkan dengan pengamalan atau pengalaman yang telah dilakukan, dalam psikologi kognitif ini disebut dengan metode visual imagery mnemonic ${ }^{10}$. Setiap akan

Journal 10, no. 1 (2019): 148-163; Akmal Mundiri and Irma Zahra, "Implementasi Metode STIFIn Dalam Meningkatkan Kemampuan Menghafal Al-Qur'an Di Rumah Qur'an STIFIn Paiton Probolinggo," Jurnal Pendidikan Agama Islam (Journal of Islamic Education Studies) 5, no. 2 (2017): 201-223; Lilik Masruroh and M. Ma'ruf, "Strategi Guru dalam Memotivasi Hafalan Juz 30 Santri Madrasah Diniyah Hidayatul Mubtadi' in Blawi Masangan Bangil," JIE (Journal of Islamic Education) 5, no. 1 (2020): 89-99.

${ }^{8}$ Lida Husniah, "Implementasi Metode Hatam Dalam Mengatasi Interferensi Retroaktif Di Taman Pendidikan Al-Qur'an Al-Barokah Way Halim Bandar Lampung" (PhD Thesis, UIN Raden Intan Lampung, 2018); H. Suwito, "Sistem Menghafal Cepat Al-Quran 40 Hari Untuk 30 Juz (Studi Di Ma'had Tahfidz al-Quran Di Dawuhan Purbalingga)," 2016.

9 Yusron Masduki, "Implikasi Psikologis Bagi Penghafal AlQur'an," Medina-Te: Jurnal Studi Islam 14, no. 1 (2018): 18-35; Hilman Haroen, "Gaya Belajar Siswa Bagi Burhanuddin Zarnuji," Ulumuddin: Jurnal Ilmu-Ilmu Keislaman 8, no. 1 (2018): 17-34.

10 Risna Rianti Sari, "Mnemonik Sebagai Alternatif Dalam Menghafal Kosakata Bahasa Arab," Tarbiyatuna: Jurnal Pendidikan Ilmiah 3, no. 2 (2018): 30-50; Luh Putu Winda Yogantari and Ni Made Ari Wilani, "Pengaruh Teknik Mnemonik Terhadap Kemampuan Membaca Aksara Bali Pada Siswa Kelas III Sekolah Dasar Negeri 1 Batubulan,” Jurnal Psikologi 
menghafal lebih baik mengulangi hafalan sebelumnya. Setiap menambah hafalan diutamakan mengulangi dahulu hafalan yang telah ada. Metode pengulangan adalah metode paling klasik dan paling terbukti berhasil dalam studi psikologi kognitif.

Jadi metode hafalan atau rote learning ini, yaitu mengulang kembali hafalan-hafalan yang telah ada, sehingga tidak lupa krtika diulang kembali, dan selanjutnya ketika anakanak sudah sedikit lebih memahami dari adik-adik dibawahnya ia bisa membantu guru mengajinya untuk menganjarkan hafalan yang telah diperoleh dari sang guru untuk mengembangkan hafalanya sehingga tidak lupa karena ia bisa bisa mengulangulangnya kembali dengan mengajarkan kepada adik-adiknya ${ }^{11}$. Guru, dalam kegiatan belajar mengajar harus merumuskan apa yang harus dilakukan siswa dan bagaimana cara mereka melakukan. Ada berbagai jenis kegiatan belajar mengajar yang bias digunakan dalam mempelajari bahan pelajaran antara lain mendengarkan, melihat, mengamati, bertanya, mengerjakan, berdiskusi, memecahkan masalah, mendemonstrasikan, melukiskan atau menggambarkan, mencoba, menghafal (rote learning), dan lain-lain.

Meskipun metode role learning ini tergolong metode klasik dan konvensional, namun untuk mengajarkan materimateri tertentu masih dianggap layak dan masih sering diterapkan seperti materi keagamaan yang harus dianjurkan untuk dihafal. Dengan kata lain metode rote learning adalah suatu teknik atau trik yang harus di kuasai oleh pendidik agar tujuan pembelajaran khusus dapat tercapai. Asumsinya, pada pembelajaran al-Qur'an, metode ini masih sangat layak untuk diterapkan, karena pembelajar al-Qura'n akan dapat membacanya dengan baik dan lancar jika mereka dapat hafal

Udayana 5, no. 3 (2018): 755-770; Idi Warsah, "Pendidikan Keimanan Sebagai Basis Kecerdasan Sosial Peserta Didik: Telaah Psikologi Islami," Psikis: Jurnal Psikologi Islami 4, no. 1 (June 8, 2018): 1-16, https://doi.org/10.19109/psikis.v4i1.2156.

11 Isnaeni Maryam, "Pengaruh Blended Learning Berbantuan Microsoft Mathematic Terhadap Kemampuan Berpikir Kreatif," Jurnal Pendidikan Surya Edukasi (JPSE) 4, no. 2 (2018): 23-34; Sari, "Mnemonik Sebagai Alternatif Dalam Menghafal Kosakata Bahasa Arab." 
dan faham ilmu tajwid (ilmu tentang tatacara membaca alQur'an dengan baik dan benar).

Sejak dahulu hingga saat ini, mengajar al-Qur'an sebenarnya ada banyak metode yang dapat diterapkan oleh sang guru seperti metode ummi, talaqqi dan lain-lain ${ }^{12}$. Tujuannya agar proses pembelajaran al-Qur'an dapat tercapai dengan baik dan benar baik tajwidnya ataupun makhraj hurufnya. Jadi metode Rote Learning juga sering diterapkan oleh guru dalam belajar al-Qur'an termasuk pembelajaran ilmu tajwid di Taman Pendidikan Al-Qur'an al-Barokah Desa Kampung Melayu, Rejang Lebong Propinsi Bengkulu. Penerapan metode ini seorang guru sangat berperan penting agar tujuan pengajaran alQur'an pada anak-anak dapat memahami dan membaca alQur'an dengan baik dan benar sesuai dengan tuntunan ilmu tajwid yang mereka pelajari. Meskipun metode bukanlah satusatunya faktor yang mempengaruhi keberhasilan proses belajar mengajar, namun keberadaannya juga sangat mempengaruhi suatu keberhasilan.

Penerapan metode apapun dalam pembelajaran alQur'an, tentu tidak akan terlepas dari peran seorang pendidik. Dengan demikian agar hasil yang dicapai bisa maksimal, seorang pendidk dituntut untuk trampil dan jeli dalam menerapkan suatu metode dan sekaligus menjadi model dalam pembelajaran tersebut ${ }^{13}$. Tanpa adanya pemilihan terhadap metode yang baik dan tepat, pembelajaral al-Qur'an tidak akan akan dapat berjalan secara efekif.

${ }^{12}$ Umi Hasunah and Alik Roichatul Jannah, "Implementasi Metode Ummi Dalam Pembelajaran Alquran Pada Santri Di Pondok Pesantren Salafiyah Al-Mahfudz Seblak Jombang," Jurnal Pendidikan Islam 1, no. 2 (2017): 160-175; Anwar Khudori, Muhamad Priyatna, and Moch Yasyakur, "Penerapan Metode Ummi Dalam Meningkatkan Kemampuan Membaca Alquran Pada Siswa Di Kelas Iv Sd Kaifa Bogor," Prosa PAI: Prosiding Al Hidayah Pendidikan Agama Islam 1, no. 2B (2019): 240-250; Rian Nuryana, Nanang Naisabur, and Hasan Bisri, "Talaqqi: Metode Membaca Al Quran di Pesantren Nurul Hikmah," Asyahid Journal of Islamic and Quranic Studies (AJIQS) 1, no. 1 (2019).

${ }^{13}$ Idi Warsah and Muhamad Uyun, "Kepribadian Pendidik: Telaah Psikologi Islami," Psikis : Jurnal Psikologi Islami 5, no. 1 (June 18, 2019): 62-73, https://doi.org/10.19109/Psikis.v5i1.3157. 
Jadi, penerapana metode rote learning dalam pembelajaran al-Qur'an di Taman pendidikan al-Qur'an dipandan tepat karena anak akan mudah menguasai dan memahami apa yang disampaikan oleh seorang guru baik pembelajaran yang berbentuk hafalan-hafalan dan lainnya. Metode rote learning dalam ilmu tajwid, sangat baik untuk diterapkan ntuk membantu anak-anak TPQ khususnya yang belum terlalu baik dan benar ilmu tajwidnya agar dapat membaca Al-qur`an dengan baik dan benar nantinya.

Sebuah penelitian menejelaskan tentang konsekuensi dari penerapan metode menghafal (Rote Learning) dalam ilmu tajwid sebagai metode pengajaran al-Qur'an sangat besar pengaruhnya terhadap keberhasilannya. Metode ini membuat guru dapat mencapai tujuan pengajaran dengan cepat dan tepat, contohnya anak-anak dapat mengetahui ilmu tajwid dengan baik dan benar, anak-anak hafal bacaan nun sukun, tanwin, dan anak-anak paham ketika ditanyai tanpa melihat buku dan bisa berpegang pada pelajaran yang telah di hafal ${ }^{14}$.

Jika merujuk pada hasil studi di atas, metode menghafal (Rote Learning) merupakan salah satu metode atau cara yang efektif dan efesien diterapkan oleh pendidik yang secara langsung memberi kemudahan bagi anak-anak untuk memepermudah anak-anak TPQ dalam memahami bacaan alQur`an dengan baik dan benar, anak-anak mampu memahami kaidah ilmu tajwid dan bisa menerapkanya tanpa melihat panduan atau bimbingan merupakan indicator keberhasilan dari penerapan metode ini.

Penerapan metode menghafal (Rote Learning) baru sebagian kecil dari metode-metode yang lainnya. Dalam mengajar Al-Qur`an guru terkadang sering mendapat kendala, karena anak-anak TPQ terkadang bisa membaca Al-Qur'an akan tetapi tidak memahami kaidah ilmu tajwid dengan baik dan benar sehingga menimbulkan masalah terhadap bacaan alQur'an yang berlangsung. Fakta ini membuktikan bahwa metode hafalan (Rote Learning) sangat dibutuhkan dalam

14 Nur, "Perbandingan Efektivitas Metode Rote Learning Dan Metode Efektif Efisien Dalam Meningkatkan Kemampuan Membaca AlQur'an Sesuai Ilmu Tajwid Di SMP Negeri 3 Surabaya.” 
mengatasi problem anak dalam belajar dan mendalami ilmu tajwid. Melalui metode ini guru bisa mengarahkankan siswanya untuk lebih mendalami ilmu tajwid dan seiring dengan berjalannya waktu bacaan al-Qur’an anak-anak bisa semakin baik lagi.

Setelah sering dibiasakan penerapan metode ini akan semakin mempermudah guru dan anak-anak dalam pembelajaran al-Qur'an, dari sinilah disadari bahwa penerapan dari metode ini sangat penting sekali dalam proses belajar mengaji dan memahami Al-Qur'an dengan baik dan benar baik makna maupun bacaanya. Akan tetapi jika anak-anak hanya mencoba-coba menghafal informasi baru tanpa menghubungkan dengan konsep-konsep yang telah ada dalam struktur kognitifnya, maka dalam hal ini terjadi belajar hafalan yang tidak bermakna, sehingga anak-anak akan mudah lupa dan sulit untuk mengingatnya kembali. Sebab kecakapan untuk menghubungkan informasi-informasi baru dengan pengertianpengertian yang telah dimiliki adalah penting. Karena struktur kognitif merupakan dasar untuk dapat menghubungkan dan menguatkan informasi-informasi baru secara teratur ${ }^{15}$.

Dalam menerapkan metode menghafal ini, ketika sang anak-anak belum memahami betul kaidah bacaan al-Qur'an dengan baik dan benar, tugas guru mengaji (ustadz/ustadzah) untuk mengarahkan sekalian memandu anak-anak dalam memahami Al-Qur'an dengan baik dan benar melalui metode hafalan ini. Ketika sang anak kembali ke rumah orang tua juga ikut berperan agar mengarahkan anak-anak mereka untuk mengulang kembali di rumah.

Sehubungan dengan hal itu, Taman Pendidikan Alqur'an (TPQ) Al-Baroqah Desa Kampung Melayu Kecamatan Bermani Ulu Kabupaten Rejang Lebong merupakan salah satu lembaga nonformal yang dijadikan sebagai obyek dari penelitian ini, dan berdasarkan hasil observasi di lapangan merupakan salah satu lembaga nonformal yang mengimplementasikan

15 Aidil Saputra, "Aplikasi Metode Contextual Teaching Learning (CTL) Dalam Pembelajaran PAI," Al-Ta'dib, VI (1), 2014, 15-46; Nurhayati Nurhayati, "Perkembangan Individu," Jurnal Teknologi Pendidikan Madrasah 2, no. 1 (2019): 26-46. 
pentingnya metode menghafal ilmu tajwid dalam proses pembelajaran al-Qur'an ${ }^{16}$. Jadi, pengajaran al-Qur'an merupakan obyek yang diamati dan guru mengaji serta anakanak TPQ Al-Baroqah sebagai subyek dari penelitian cukup beralasan karena di TPQ ini banyak anak-anak yang sudah bisa membaca Al-qur'an akan tetapi belum memahami ilmu tajwid dengan baik. Berangkat dari asumsi dan argumentasi inilah peneliti berusaha menemukan gambaran implementasi metode menghafal (Rote Learning) dalam ilmu tajwid untuk meningkatkan kemampuan membaca Al-Qur'an dengan baik dan benar di TPQ Al Baroqah Desa Kampung Melayu kecamatan bermani ulu kabupaten Rejang Lebong.

Jenis penelitian adalah penelitian kualitatif, dengan tujuan mendeskripsikan Implementasi Metode Rote Learning Dalam ilmu Tajwid untuk meningkatkan keberhasilan membaca Al-Qur'an dengan baik dan benar di TPQ Al Baroqah Desa Kampung Melayu Kecamatan Bermani Ulu Kabupaten Rejang Lebong. Subyek dalam penelitian ini adalah guru ngaji/ustadzah, anak-anak TPQ, dan orang tua anak-anak Taman Pendidikan AlQur'an (TPQ) Al-Baroqah. Pengumpulan data dilaksanakandengan menggunakan teknik observasi dan wawancara. Setelah data dikumpulkan dan dilakukan reduksi data, kemudian dianalisis menggunakan metode deduktif dan induktif guna memperoleh simpulan sebagai jawaban permsalahan tentang implementasi metode rote learning dalam ilmu tajwid untuk meningkatkan keberhasilan membaca AlQur'an dengan baik dan benar di TPQ Al Baroqah tersebut ${ }^{17}$.

\section{PEMBAHASAN}

Paparan hasil penelitian yang dilakukan di lapangan tentang penggunaan metode menghafal (Rote Learning) ilmu tajwid dalam pengajaran Al-Qur'an dengan baik dan benar di Taman Pendidikan al-Qur'an Al-Baroqah Desa Kampung Melayu Kecamatan Beramani Ulu di dapatkan dua aspek gambaran yaitu implementasi metode menghafal (Rote

${ }^{16}$ Data hasil Observasi 1 Januari 2020

${ }^{17}$ Matthew B. Miles, M. A. Huberman, and J. Saldana, "Qualitative Analysis: An Expanded Sourcebook," Thousand Oaks, CA: Sage, 1994. 
Learning) dan efektivitas dalam pembelajaran al-Qur`an dengan baik dan benar ketika metode tersebut digunakan.

\section{Penerapan Metode Menghafal (Rote Learning) di Taman Pendidikan Al-Quran (TPQ) Al-Baroqah Desa Kampung Melayu Kecamatan Bermani Ulu}

Berdasarkan data yang diperoleh dari hasil wawancara di Taman Pendidikan Al-Qur'an Al-Baroqah Desa Kampung Melayu kecamatan bermani ulu, bahwa penerapan metode menghafal (Rote Learning) pada pengajaran al-Qur'an dengan baik dan benar sudah berlangsung sejak lama yaitu ketika Taman Pendidikan Al-qur'an (TPQ) Al-Baroqah itu didirikan dan metode ini di terapkan setiap kali petemuan mengaji yaitu pada sore hari. Alasan guru ngaji menggunakan metode ini setelah metode menghafal (Rote Learning) ini diterapkan sangat membawa dampak yang positif pada anak-anak TPQ ini, dimana dahulu anak-anak belum memahami kaidah ilmu tajwid dengan baik, sehingga berdampak pula dengn bacaan al-Qur'annya, tapi setelah metode ini diterapkan anak-anak bacaan Al-Qur'annya semakin hari semakin lebih baik.

Ustadzah Mayana selaku pengasuh Taman Pendidikan al-Qur'an (TPQ) Al-Baroqah Desa Kampung Melayu Kecamatan Bermani Ulu menceritakan bahwa: "Metode menghafal (Rote Learning) selalu dilakukan ketika tiap kegiatan belajar mengajar Al-qur`an dimulai sampai kegiatan mengaji selesai. Metode menghafal (Rote learning) ini benar-benar membawa dampak yang signifikan karena dari hari ke hari bacaan al-Qur'an anak-anak Taman Pendidikan Al-Qur'an (TPQ) Al-Baroqah Desa Kampung Melayu semakin lebih baik, misalnya hafalan ilmu tajwidnya, kaidah bacaan makhraj hurufnya, serta bacaan al-Qur'annya"18. Itu baru merupakan sebagian kecil saja contoh manfaat metode menghafal (Rote Learning) di Taman Pendidikan al-Qur'an (TPQ) al-Baroqah Desa Kampung Melayu Kecamatan Bermani Ulu. Adapun dampak positif yang lainnya yaitu, mereka sudah bisaa membantu adik-adiknya yang lain yang belum memahami kaidah ilmu tajwid, dan bacaan al-Qur'annya yang belum terlalu sempurna, serta mereka sudah mulai belajar mengaji irama

${ }^{18}$ Data hasil Wawancara 5 Februari 2020 
menggunakan irama bayati, syika, jiharka dan lain-lain, karena ilmu tajwid yang sudah mereka pelajari.

Terkait dengan adanya metode hafalan (Rote Learning) Ustad Syamsul Putra ustdazah Mayana yang membantu mengajar mengaji Al-Qur'an di Taman Pendidikan Al-Qur'an Al-Baroqah Desa Kampung Melayu kecamatan bermani ulu menyatakan bahwa." Metode hafalan (Rote Learning) yang diterapkan untuk mengajar anak-anak di TPQ Al-Baroqah ini benar-benar membawa dampak yang positif karena yang ia lihat setiap hari ketika mengajar, anak sudah bisa memahmi kaidah ilmu tajwid seperti hukum nun mati, tanwin, hukum mad tabii, dan lain-lain yang membawa dampak yang sangat baik untuk bacaan Al-Qur'an di Taman Pendidikan al-Qur'an Al-Baroqah Desa Kampung Melayu Kecamatan Bermani Ulu."19 Taman Pendidikan Al-qur'an (TPQ) al-Baroqah Desa Kampung Melayu menerapkan metode ini dari awal pengajian sampai akhir kegiatan belajar mengajar, seperti awalnya ditanya dulu apa itu hukum nun mati, serta apa contohnya dan lain-lain.

Untuk memperkuat data di atas, Latifah anak asuh Taman pendidikan al-Qur'an Al-Baroqah (TPQ) yang bisa dikatakan adalah murid senior dari adik-adiknya yang lain juga sudah mulai membantu ustadzah Mayana mengajar Al-Qur'an menyatakan bahwa". Metode hafalan (Rote Learning) dalam ilmu tajwid di Taman Pendidikan Al-Qur'an (TPQ) Al-Baroqah Desa Kampung Melayu ini, dimulai dari hal yang sederhana, seperti diadakan dulu Tanya jawab tentang tajwid, kemudian anak-anak TPQ dites untuk menunjukkan contoh, misalnya nun mati hukumnya apa, dan contohnya apa kemudian diminta untuk membacakan satu ayat Al-Qur'an yang berkenaan dengan contoh ilmu tajwid yang sudah diajarkan." 20

Berdasarkan semua itu, metode hafalan (Rote Learning) yang diterapkan di Taman Pendidikan al-Qur'an al-Baroqah (TPQ) Desa Kampung Melayu dari hasil wawancara dengan anak TPQ, metode menghafal dalam ilmu tajwid yang telah diterapkan diperkuat dengan hasil observasi pada saat kegiatan belajar mengajar di Taman Pendidikan Al-Qur'an (TPQ)

\footnotetext{
${ }^{19}$ Data hasil Wawancara 15 Februari 2020

${ }^{20}$ Data hasil Wawancara 20 Februari 2020
} 
terlihat jelas bahwa metode rote learning ini telah membawa dampak yang positif bagi anak-anak TPQ yang semakin mendapatkan kemudahan dalam belajar Al-Qur'andengan lebih baik. Sementara guru dipermudah dengan adanya metode tersebut. ${ }^{21}$ Hal ini membuktikan bahwa di Taman Pendidikan Al-Qur'an (TPQ) Al-Baroqah benar-benar telah menerapkan metode menghafal (Rote Learning) ini. Fakta tersebut dapat dilihat bahwa anak-anak TPQ Al-Baroqah telah merasakan dampak yang signifikan dari penerapan metode hafalan (Rote Learning) pada kegiatan belajar Al-Qur'an di TPQ tersebut.

Bagaimana tanggapan dan pendapat orang tua/wail dari anak-anak TPQ Al-Baroqah setelah diterapkannya metode ini? Dalam kesempatan ini peneliti melakukan wawancara kepada orang tua/wali dari anak-anak TPQ al-Baroqah:" Metode hafalan (Rote Learning) yang diterakan di Taman Pendidikan Al-Qur'an (TPQ) Al-Baroqah, benar-benar telah membuat anak-anak terbantu, dan ketika di rumah mereka sudah bisa mengajarkan adik-adiknya cara membaca Al-Qur'an dengan baik dan benar itu semua karena dampak positif dari penerapan metode ini di tempat anak-anak belajar mengaji." 22 Pendapat ini juga dibenarkan oleh orang tua/wali anak-anak TPQ yang lain seperti bapak Effendi, menyatakan bahwa: "Metode tersebut benarbenar telah membantu bahkan anak-anak sudah lebih paham tentang kaidah bacaan Al-Qur'an yang baik itu seperti apa dan bahkan hafalan dan pengetahuan mereka tentang ilmu tajwid jauh lebih banyak dari kita sebagai orang tua dan itu tentu saja membuat bangga orang tua". ${ }^{23}$

Argumentasi di atas diperkuat oleh Ustadz Mardiono, suami dari Ustadzah Mayana bahwa pengajaran Al-Qur'an dengan baik dan benar di Taman Pendidikan Al-Qur'an AlBaroqah Desa Kampung Melayu Kecamatan Bermani Ulu, sudah ada sejak TPQ tersebut berdiri, penerapan metode menghafal (Rote Learning) dalam ilmu tajwid ini, bisa diterapkan dengan baik dalam pembelajaran Al-Qur'ankarena adanya kombinasi yang baik dari kami selaku pengajar, anak-

${ }^{21}$ Data Wawancara 27 Februari 2020

22 Data Wawancara 30 Februari 2020

${ }^{23}$ Data Wawancara 30 Februari 2020 
anak TPQ selaku pelaksana, dan orang tua/atau wali juga berperan ketika anak-anak belajar al-Qur'an dirumahnya, sehingga anak-anak memiliki ilmu tajwid yang baik dan berefek pada bacaan Al-Qur'annya yang menjadi semakin baik dar hari ke hari.

Berdasarkan paparan data di atas, dapat disimpulkan bahwa gambaran penerapan metode menghafal (Rote Learning) dalam ilmu tajwid Pada pengajaran Al-Qur'an dengan baik dan benar di Taman Pendidikan Al-Qur'an (TPQ) Al-Baroqah sudah berjalan dengan sangat baik, karena anak-anak sudah bisa memahami kaidah ilmu tajwid dengan baik, dan bacaan AlQur'annya juga sudah semakin baik, dan juga kerjasama yang baik antara guru ngaji dengan orang tua/wali untuk mengontrol aktivitas belajar Al-Qur'an anak-anak baik ketika belajar di TPQ maupun ketika mengulang kembali di rumah. Sebaik apapun metode yang digunakan oleh guru dalam membina perilaku siswa melalui proses pembelajaran tidak akan memperoleh hasil yang baik jika tidak terjalin kerja sama antara sekolah, orang tua dan masyarakat.

\section{Evektivitas Metode Menghafal (Rote Leraning) dalam ilmu Tajwid untuk meningkatkan Keberhasilan membaca Al- Qur'an}

Guru ngaji merupakan pendidik nonformal yang keberadaannya sangat dibutuhkan ditengah-tengah masyarakat dan memliki peran yang sangat penting dan strategis dan kebutuhan akan guru ngaji adalah keniscayaan yang tidak bisa dipungkiri, masyarakat dalam hal ini umat islam percaya dengan memasrahkan pendidikan keagamaan untuk anak-anak mereka sekaligus pendidikan moral/akhlak islami kepada guru ngaji. Orang tua sebagai guru pertama ari anak sangat terbantu dengan adanya lembaga pendidikan seperti TPQ, apa lagi orang tua sehari-hari sibuk di lading atau aktivitas lain, mereka merasa khawatir akan pendidikan agama sang anak dikemudian hari dan sumber/landasan pendidikan agama dalam Islam adalah alQur'an ${ }^{24}$. Artinya disadari atau tidak, terbukti bahwa guru ngaji

24 Bambang Budiman, Zubaidah, And Syafwan, "Perancangan Komik Edukasi Sosial Islamiah: Mahmud Dan Sholeh," Dekave: Jurnal Desain Komunikasi Visual 7, No. 2 (2018); Abdul Halim, "Islam dan Hak 
hingga saat ini merupakan variable penting dalam meminimalisir dampak-dampak negative dan arus informasi, dan globalisasi sebagai penjaga system nilai di lingkungan masing-masing dan itulah peran ngaji dan lembaga pendidikan keagamaan pada umumnya.

Untuk memperoleh data yang valid tentang efektivitas pelaksanaan pembelajaran Al-qur'an dengan baik dan benar di Taman Pendidikan Al-Qur'an (TPQ) Al-Baroqah Desa kampung melayu kecamatan bermani ulu, peneliti mencoba mewawancarai pengasuh sekaligus guru ngaji, beliau menjelaskan bahwa: "sebagai guru ngaji di TPQ al-Baroqah, selalu memberikan pengajaran dan budi pekerti yang baik, seperti motivasi belajar kepada anak-anak TPQ, memperingatkan agar mau mengulang-ulang kembali hafalan yang telah dipelajari sebelumnya, diadakan tanya jawab untuk mengingat kembali hafalan mereka, diadakan game cepat tepat seputar ilmu tajwid dan Al-Qur'an sehingga dengan kombinasi seperti itu maka penerapan metode menghafal (Rote Learning) dalam ilmu tajwid bisa di terapkan dengan sangat baik dan membawa manafaat yang siginfikkan ketika digunakan saat proses belajar Al-Qur'an dengan baik dan benar". ${ }^{25}$

Dapat dipahami bahwa guru ngaji/Ustadzah tidak hanya membuat rencana atau kebijakkan semata, akan tetapi harus juga belajar meningkatkan inovasi-inovasi, terutama dalam menerapkan metode menghafal (Rote Learning) agar anak-anak tidak bosan, dan menjadi lebih bervariasi ketika metode tersebut diterapkan. Sehingga metode ini bisa dijadikan metode pokok di Taman Pendidikan Al-Qur'an Al-Baroqah desa kampung melayu dan semakin banyak membawa dampak yang positif dalam proses belajar Al-Qur'an.

Data dari hasil observasi menunjukkan bahwa untuk mengetahui peran guru ngaji pada terkait dengan penggunaan metode hafalan (Rote Learning) yang dilakukan di Taman Pendidikan Al-Qur'anAl-Baroqah Desa kampung melayu oleh Ustadz Syamsul yang menjadi guru bantu di TPQ Al-Baroqah

Asasi Manusia Dalam Perspektif Fathi Osman," In Right: Jurnal Agama Dan Hak Azazi Manusia 1, No. 1 (2017).

${ }^{25}$ Wawancara 2 maret 2020 
bahwa memang peran guru ngaji memang sangat dibutuhkan oleh anak-anak TPQ terutama inovasi yang baru dalam proses belajar mengajar seputar Al-Qur'an untuk membantu anak-anak TPQ meningkatkan keberhasilan membaca al-Qur'an sekaligus paham ilmu tajwidnya dengan baik ${ }^{26}$. Jika dilihat dari pernyataan tersebut memang benar bahwa pernyataan yang disampaikan sang guru ngaji perannya dalam menerapkan metode hafalan (Rote Learning) di Taman Pendidikan al-Qur'an al-Baroqah desa kampung melayu itu benar.

Selanjutnya untuk memastikan untuk memastikan kembali yang dibuat tersebut maka peneliti kembali mewawancarai Latifah murid senior yang membantu mengajar di TPQ Al-Baroqah ini ia berpendapat bahwa ustadzah Mayana selaku guru ngaji sangat mengutamakan metode hafalan (Rote Learning) dalam ilmu tajwid dan bahkan sampai anak-anak Taman Pendidikan Al-baroqah Desa kampung melayu semuanya paham dan menguasai kaidah ilmu tajwid serta tercermin dalam bacaan al-Qur'annya. Sebab karena metode ini benar-benar sudah membawa dampak yang positing, karena murid di permudah dalam memahmi kaidah bacaan Al-qur'an dan guru ngaji di permudah dengan adanya metode ini $^{27}$.

Terkait dengan semua itu minat dan kemauan anak-anak TPQ terhadap metode menghafal (Rote Learning) dalam belajar Al-Qur'an yang dilakukan di Taman Pendidikan Al-Qur'an (TPQ) Al-Baroqah Desa kampung melayu, Ustadz Mardiono menyatakan bahwa .:"Membangkitkan minat belajar anak-anak TPQ terhadap al-Qur'an dengan inovasi yang baru, seperti gam cepat tepat, Tanya jawab, dan lain-lain yang menarik minat anak-anak TPQ dengan menggunakan metode menghafal (Rote Learning) ketika melakukan kegiatan belajar mengajar yang dilakukan setiap hari" 28 .

Sehubungan dengan beberapa pendapat diatas juga dibenarkan oleh beberapa orang tua/wali dari anak-anak TPQ Al-baroqah/ Ibu Deni Aryani S.PdI menyatakan bahwa: "sebagai orang tua/wali dari anak-anak merasa sangat terbantu

\footnotetext{
${ }^{26}$ Observasi dan wawancara 5 maret 2020

${ }^{27}$ Data Wawancara 10 Maret 2020

${ }^{28}$ Data Wawancara 13 Maret 2020
} 
dalam mendidik anak ilmu Al-Qur'an di rumah karena benarbenar membawa manfaat bagi si anak, misalnya anak-anak ketika di Tes mengaji oleh orang tuanya, mereka sudah bisa menjelaskan tentang hukum bacaannya seperti hukum bacaan nun mati, tanwin, mad Tabii dan lain-lain, dan anak-anak benar bisa mamahami kaidah bacaan Al-Qur'andengan lebih baik dan tentu saja membuat orang tua bangga kepada anak-anaknya." ${ }^{29}$ Lebih lanjut ada juga orang tua/wali dari anak-anak TPQ AlBaroqah lainnya yaitu bapak Sohari menyatakan Bahwa:"Penerapan metode menghafal (Rote Learning) ketika proses belajar mengara di TPQ Al-Baroqah benar-benar berdampak baik pada pembelajaran Al-Qur'an anak-anak dan penggunaan metode ini merupakan keunggulan dan mempunyai nilai lebih tersendiri dibandingkan dengan TPQ-TPQ yang lainnya." 30 Dapat ditarik kesimpulan bahwa orang tua sangat terbantu, serta sanga bahagia dengan adanya penerapan dari metode hafalan (Rote Learning ) ini.

Beberapa argumentsi di atas menggambarkan beberapa indikator penting bahwa proses kegiatan pembelajaran al-Qur'an dengan menggunakan metode hafalan (Rote Learning) dalam ilmu tajwid ketika belajar al-Qur'an sudah sangat efektif sekali, digunakan untuk membuat anak-anak lebih cepat memahami kaidah ilmu tajwid serta bacaan Al-Qur'annya yang semakin menjadi lebih baik di Taman Pendidikan Al-Qur'an (TPQ) AlBaroqah desa Kampung Melayu Kecamatan Bermani Ulu Kabupaten Rejang Lebong. Asumsi ini diperkuat oleh hasil observasi tehadap kemajuan anak-nak TPQ Al-Baroqah dalam pembelajarn Al-Qur'an, mereka sangat antusias sekali ketika proses belajar mengaji sedang beralangsung, ketika diadakan Tanya jawab seputar ilmu tajwid dan contohnya dalam AlQur'an mereka langsung bisa menjawab dengan tepat dan ketika diminta membacakan bacaan Al-Qur'an dengan kaidah ilmu tajwid yang ada, misalnya bacaan Al-Qur'an yang ada hukum bacaan ikhfa nya mereka langsung bisa mempraktekkan bacaan tersebut tanpa ragu lagi ${ }^{31}$.

\footnotetext{
${ }^{29}$ Data Wawancara 15 Maret 2020

${ }^{30}$ Data Wawancara 17 Maret 2020

${ }^{31}$ Observasi 20 Maret 2020
} 
Pemaparan data dan hasil observasi dilapangan penelitian menjadi argument yang sangat kuat bahwa penerapan metode hafalan (Rote Learning) sangat efektif dalam proses pembelajaran Al-Qur'an dengan baik dan benar tidak hanya Taman Pendidikan Al-Qur'An (TPQ) Al-Baroqah yang merasakan dampak positifnya, akan tetapi anak-anak TPQ serta orang tuanya, dan pihak-pihak terkait lainnya juga merasakan dampak yang positif dan signifikkan karenanya. Mengenai efektivitas penggunaan metode hafalan (Rote Learning) dalam ilmu tajwid ini, Ustadzah Mayana selaku pengasuh Taman Pendidikan Al-Baroqah Desa Kampung Melayu Kecamatan Bermani Ulu Menyatakan Bahwa: "Taman Pendidikan Alqur'an Al-baroqah memiliki nilai lebih tersendiri di bandingkan tempat-tempat belajar mengaji yang lainnya seperti anak-anak yang sudah bisa membaca Al-Qur'an ditekankan untuk paham kaidah ilmu tajwidnya, dan diperbaik bacaan Alqur'annya dengan ilmu tajwid yang diajarkan sehingga tujuan membentuk anak-anak generasi Al-Qur'an yang paham Al-Qur'an dengan baik bisa terealisasikan" 32 .

Paparan data di atas, menunjukkan bahwa penggunaan metode menghafal (Rote Learning) dalam ilmu tajwid yang di terapkan di Taman Pendidikan Al-Quran (TPQ) Al-Baroqah desa kampung melayu kecamatan Bermani Ulu, telah membawa dampak yang sangat positif dan penggunaan metode menghafal (Rote Learning) dalam ilmu tajwid pada proses kegiatan belajar mengajar Al-Qur'an sangat efektif digunakan karena membantu guru ngaji dalam mengajar kaidah ilmu tajwid serta bisa diterapka dalam bacaan Al-Qur'annya.

Data tersebut terlihat dengan jelas bahwa gurulah yang memliki peran penting terhadap pengembangan potensi anak didiknya dan pada diri setiap manusia telah tersedia potensi energi atau sebuah kekuatan yang dapat menggerakkan dan mengarahkan tingkah lakunya pada tujuan, di dalamnya tercakup pula potensi energi/kekuatan untuk berprestasi (motif berprestasi) yang kekuatannya berbeda pada setiap manusia. Potensi energi berprestasi ini keadaannya akan meningkat bahkan akan menggerakkan dan mengarahkan pada tingkah laku

32 Data Wawancara 23 Maret 2020 
belajar $^{33}$. Untuk membangkitkan minat pengetahuan anak-anak tentang al-Qur'an banyak variasi dan cara yang diterapkan dan diciptakan inovasi-inovasi yang baru di Taman Pendidikan Alqur'an Al-Baroqah Desa Kampung Melayu Kecamatan bermani Ulu, akan membuat suasana pembelajaran Al-Qur'an dengan baik dan benar disenangi oleh anak-anak dan akan membawa hasil yang maksimal sehingga lebih banyak lagi membawa manfaat.

Pengajaran Al-Qur'an dengan baik dan benar dengan menggunakan metode hafalan (Rote Learning), perlu disesuaikan dengan karakteristik anak-anak masing-masing karena pada umunya karakteristika anak-anak itu berbeda-beda, ada yang memiliki kemauan yang tinggi, ada yang memiliki kemauan yang rendah, dan ada yang cepat mengerti apa yang disampaikan namun ada juga yang lambat mengerti terhadap apa yang disampaikan. Apalagi waktu belajar yang juga sangat terbatas sekali, dan problem-problem dalam proses pembelajaran tersebut, tentunya semua itu harus ada peran dan dorongan pendidik didalamnya agar motivasi belajar al-Qur'an membuat anak-anak semakin tertarik mengkiuti dan mengaflikasikannya.

Guru ngaji/Ustadz harus juga mempertimbangkan dan menyadari, bahwa tidak semua metode, bahan ajara/media pembelajaran anak-anak itu menarik perhatian mereka, karena itu guru bisa memberi pengertian maupun penjelasan sekaligus motivasi kepada anak-anak yang diasuh untuk menarik perhatian mereka agar lebih semangat memepelajari al-Qur'an dengan sebaik-baiknya dan memotivasi mereka bahwa Al-Qur'an akan membawa manfaat bagi mereka baik di dunia maupun di akherat.

Berdasarkan data hasil observasi dan wawancara yang dilkukan oleh peneliti diperoleh jawaban bahwa penerapan metode Rote Learning dalam ilmu Tajwid untuk meningkatkan

${ }^{33}$ Hairuddin Cikka, "Strategi Komunikasi Guru Memotivasi Peserta Didik Dalam Meningkatkan Prestasi Belajar," Al-Mishbah: Jurnal Ilmu Dakwah Dan Komunikasi 15, no. 2 (2020): 359-38; Indrati Endang Mulyaningsih, "Pengaruh Interaksi Sosial Keluarga, Motivasi Belajar, Dan Kemandirian Belajar Terhadap Prestasi Belajar," Jurnal Pendidikan Dan Kebudayaan 20, no. 4 (2014): 441-451. 
keberhasilan membaca Al-Qur'an dengan baik dan benar di Taman Pendidikan Al-Quran (TPQ) Al-Baroqah Desa Kampung Melayu Kecamatan Bermani Ulu Kabupaten Rejang Lebong ditemukan gambaran bahwa anak-anak TPQ Al-Baroqah sudah pandai membaca Al-Qur'an dan menerapkan kaidah ilmu tajwid didalamnya, pandai dalam mengaji irama karena ilmu tajwid yang sudah dipahami, menegtahui bagian-bagian dari ilmu tajiwid yang ada seperti hokum nun mati/Tanwin, Mad Tabii dan lain-lain dan dampak dari keberhasilan penggunaan metode tersebut tidak hanya dilingkungan belajar TPQ saja akan tetapi di rumah, dan juga masyarakat.

\section{KESIMPULAN}

Penerapan meteode menghafal (Rote Learning) dalam ilmu tajwid dipandang sangat efektif untuk diterapkan terutama dalam proses pembeljajaran Al-Qur'an dengan baik dan benar berdasarkan kaidah ilmu tajwid yang diterapkan pada anak-anak ketika proses belajar Al-Qur'an berlangsung. Terbukti bahwa penerapan metode tersebut sudah terlihat manfaatnya pada bacaan al-Qur'an anak-anak asuh di TPQ Al-Baroqah seperti sudah bisa memperaktekkan bacaan Al-Qur'an dengan baik ketika di tes kembali oleh guru ngaji yang bersangkutan anakanak dapat menjawab ketika diminta memberika contoh bacaan penerapan ilmu tajwid dalam Al-Qur'an dengan benar dan tepat, bisa mengaji dengan kaidah ilmu tajwid ketika anak diminta mengaji di sebuah hajatan, atau ketika peringatan hari besar islam dan lain-lain. Penelitian ini memberikan saran kepada pembima TPQ al-Barokan agar tetap mempertahankan metode ini di terapak di lembagan pendidikan al-Qur'an tersebut. 


\section{DAFTAR PUSTAKA}

Amalia, Aisyah Nur. "Dinamika Tes Peringkat Hafalan." AlFanar: Jurnal Ilmu Al-Qur'an Dan Tafsir 2, no. 1 (2019): 1-14.

Astawa, I. Nyoman Temon. "Teori-Teori Dalam Dunia Pendidikan Modern.” Jurnal Penjaminan Mutu 1, no. 1 (2016): 67-72.

Astuti, Wahyu, and Firosalia Kristin. "Penerapan Model Pembelajaran Teams Games Tournament Untuk Meningkatkan Keaktifan Dan Hasil Belajar IPA.” Jurnal Ilmiah Sekolah Dasar 1, no. 3 (2017): 155-162.

Bambang Budiman, Zubaidah, and Syafwan. "Perancangan Komik Edukasi Sosial Islamiah: Mahmud Dan Sholeh." Dekave: Jurnal Desain Komunikasi Visual 7, no. 2 (2018).

Cikka, Hairuddin. "Strategi komunikasi guru memotivasi peserta didik dalam meningkatkan prestasi belajar." $\mathrm{Al}$ Mishbah: Jurnal Ilmu Dakwah Dan Komunikasi 15, no. 2 (2020): 359-38.

Eka, Besse Tantri. "Penerapan Metode Jibril Dalam Meningkatkan Kemampuan Menghafal QS. Al-Insyiqoq ayat 1-25 di Ma'had Al-Jami'ah Uin Raden Fatah Palembang (Skripsi)." PhD Thesis, UIN Raden Fatah Palembang, 2016.

Erwinsyah, Alfian. "Manajemen Kelas Dalam Meningkatkan Efektifitas Proses Belajar Mengajar." Tadbir: Jurnal Manajemen Pendidikan Islam 5, no. 2 (2017): 87-105.

Halim, Abdul. "Islam Dan Hak Asasi Manusia Dalam Perspektif Fathi Osman." IN RIGHT: Jurnal Agama Dan Hak Azazi Manusia 1, no. 1 (2017).

Haroen, Hilman. "Gaya Belajar Siswa Bagi Burhanuddin Zarnuji." Ulumuddin: Jurnal Ilmu-Ilmu Keislaman 8, no. 1 (2018): 17-34. 
Hasunah, Umi, and Alik Roichatul Jannah. "Implementasi Metode Ummi Dalam Pembelajaran Alquran Pada Santri Di Pondok Pesantren Salafiyah Al-Mahfudz Seblak Jombang." Jurnal Pendidikan Islam 1, no. 2 (2017): $160-175$.

Hidayat, Fattah. "Kajian Psikologi Pembelajaran Hafal Quran Bagi Anak Usia Dini." In Proceedings of The 2nd Annual Conference on Islamic Early Chilhood Education, 3:83-94, 2017.

Husniah, Lida. "Implementasi Metode Hatam dalam Mengatasi Interferensi Retroaktif Di Taman Pendidikan Al-Qur'an Al-Barokah Way Halim Bandar Lampung." PhD Thesis, UIN Raden Intan Lampung, 2018.

Khudori, Anwar, Muhamad Priyatna, and Moch Yasyakur. "Penerapan Metode Ummi Dalam Meningkatkan Kemampuan Membaca Alquran Pada Siswa Di Kelas Iv Sd Kaifa Bogor." Prosa PAI: Prosiding Al Hidayah Pendidikan Agama Islam 1, no. 2B (2019): 240-250.

Lutfiyah, Eva. "Pengaruh Penerapan Metode Rote Learning Dalam Pembelajaran Al-Qur'an Dan Hadits Terhadap Keberhasilan Membaca Al-Qur'an (Studi Di MTs Negeri 2 Kota Serang." PhD Thesis, Universitas Islam Negeri" Sultan Maulana Hasanuddin" Banten, 2018.

Mamlu'ah, Aya. "Metode Lotre Pesantren Tahfidz Al-Qur'an At-Tauhid Leran Senori Tuban Analisis Terhadap Pencapaian Hafalan Al-Qur'an dan Permasalahannya." Visipena Journal 10, no. 1 (2019): 148-163.

Maryam, Isnaeni. "Pengaruh Blended Learning Berbantuan Microsoft Mathematic Terhadap Kemampuan Berpikir Kreatif." Jurnal Pendidikan Surya Edukasi (JPSE) 4, no. 2 (2018): 23-34.

Masduki, Yusron. "Implikasi Psikologis Bagi Penghafal AlQur'an." Medina-Te: Jurnal Studi Islam 14, no. 1 (2018): 18-35. 
Masruroh, Lilik, and M. Ma'ruf. "Strategi Guru dalam Memotivasi Hafalan Juz 30 Santri Madrasah Diniyah Hidayatul Mubtadi'in Blawi Masangan BangiL." JIE (Journal of Islamic Education) 5, no. 1 (2020): 89-99.

Miles, Matthew B., M. A. Huberman, and J. Saldana. "Qualitative Analysis: An Expanded Sourcebook." Thousand Oaks, CA: Sage, 1994.

Moleong, Lexi J. Methodology of Qualitative Research. Bandung: Remaja Rosda Karya, 2010.

Mulyaningsih, Indrati Endang. "Pengaruh Interaksi Sosial Keluarga, Motivasi Belajar, Dan Kemandirian Belajar Terhadap Prestasi Belajar." Jurnal Pendidikan Dan Kebudayaan 20, no. 4 (2014): 441-451.

Mundiri, Akmal, and Irma Zahra. "Implementasi Metode STIFIn Dalam Meningkatkan Kemampuan Menghafal Al-Qur'an Di Rumah Qur'an STIFIn Paiton Probolinggo." Jurnal Pendidikan Agama Islam (Journal of Islamic Education Studies) 5, no. 2 (2017): 201-223.

Nugraha, Muldiyana. "Manajemen Kelas Dalam Meningkatkan Proses Pembelajaran." Tarbawi: Jurnal Keilmuan Manajemen Pendidikan 4, no. 01 (2018): 27-44.

Nur, Fitri Ardhiana. "Perbandingan Efektivitas Metode Rote Learning Dan Metode Efektif Efisien Dalam Meningkatkan Kemampuan Membaca Al-Qur'an Sesuai Ilmu Tajwid Di SMP Negeri 3 Surabaya." PhD Thesis, UIN Sunan Ampel Surabaya, 2018.

Nurhayati, Nurhayati. "Perkembangan Individu." Jurnal Teknologi Pendidikan Madrasah 2, no. 1 (2019): 26-46.

Nuryana, Rian, Nanang Naisabur, and Hasan Bisri. "Talaqqi: Metode Membaca Al Quran di Pesantren Nurul Hikmah." Asyahid Journal of Islamic and Quranic Studies (AJIQS) 1, no. 1 (2019).

Roulston, Kathryn. "Analysing Interviews." The SAGE Handbook of Qualitative Data Analysis, 2014, 297-312. 
Saputra, Aidil. "Aplikasi Metode Contextual Teaching Learning (CTL) Dalam Pembelajaran PAI." Al-Ta'dib, VI (1), 2014, 15-46.

Sari, Risna Rianti. "Mnemonik Sebagai Alternatif Dalam Menghafal Kosakata Bahasa Arab." Tarbiyatuna: Jurnal Pendidikan Ilmiah 3, no. 2 (2018): 30-50.

Sulfemi, Wahyu Bagja. "Penerapan Model Pembelajaran Discovery Learning Meningkatkan Motivasi Dan Hasil Belajar Pendidikan Kewarganegaraan." Jurnal Rontal Keilmuan Pancasila Dan Kewarganegaraan 5, no. 1 (2019).

Sunarti, Iin, and Nita Ristiani. "Pengaruh Penerapan Model Pembelajaran Problem Solving Berbasis Mind Mapping Terhadap Kemampuan Berpikir Kritis Siswa (Studi Eksperimen Pada Siswa Kelas VIII Mata Pelajaran IPS Terpadu di SMP Negeri 1 Kuningan)." Equilibrium: Jurnal Penelitian Pendidikan Dan Ekonomi 15, no. 01 (2018): 18-34.

Suwito, H. "Sistem Menghafal Cepat Al-Quran 40 Hari Untuk 30 Juz (Studi di Ma'had Tahfidz al-Quran Di Dawuhan Purbalingga)," 2016.

Warsah, Idi. "Interkoneksi Pemikiran Al-Ghazāli Dan Sigmund Freud Tentang Potensi Manusia." Kontekstualita 32, no. 01 (January 26, 2018). http://ejournal.lp2m.uinjambi.ac.id/ojp/index.php/Kontekstualit $\mathrm{a} /$ article/view/30.

- "Pendidikan Keimanan Sebagai Basis Kecerdasan Sosial Peserta Didik: Telaah Psikologi Islami." Psikis : Jurnal Psikologi Islami 4, no. 1 (June 8, 2018): 1-16. https://doi.org/10.19109/psikis.v4i1.2156.

Warsah, Idi, and Muhamad Uyun. "Kepribadian Pendidik: Telaah Psikologi Islami." Psikis : Jurnal Psikologi Islami 5, no. 1 (June 18, 2019): 62-73. https://doi.org/10.19109/Psikis.v5i1.3157. 
Jurnal Paedagogia Vol. 9 No. 1 Maret 2020

Yogantari, Luh Putu Winda, and Ni Made Ari Wilani. "Pengaruh Teknik Mnemonik Terhadap Kemampuan Membaca Aksara Bali Pada Siswa Kelas III Sekolah Dasar Negeri 1 Batubulan.” Jurnal Psikologi Udayana 5, no. 3 (2018): 755-770. 